Article

\title{
Improving the Stability of Oil Body Emulsions from Diverse Plant Seeds Using Sodium Alginate
}

\author{
Yuemei Zhang ${ }^{1}$, Nan Yang ${ }^{1,2}, * \mathbb{E}$, Yao Xu ${ }^{1}$, Qian Wang ${ }^{1}$, Ping Huang ${ }^{1}$, Katsuyoshi Nishinari ${ }^{1,2}$ \\ and Yapeng Fang ${ }^{1,2}$ \\ 1 Glyn O. Phillips Hydrocolloid Research Centre, National "111" Center for Cellular Regulation and \\ Molecular Pharmaceutics, Key Laboratory of Fermentation Engineering (Ministry of Education), \\ Department of Bioengineering and Food Science, Hubei University of Technology, Wuhan 430068, China; \\ zym19950721@163.com (Y.Z.); xy15827478521@163.com (Y.X.); yingzi415768596@163.com (Q.W.); \\ huangpipi0601@163.com (P.H.); katsuyoshi.nishinari@gmail.com (K.N.); ypfang@sjtu.edu.cn (Y.F.) \\ 2 Food Hydrocolloid International Science and Technology Cooperation Base of Hubei Province, \\ Hubei University of Technology, Wuhan 430068, China \\ * Correspondence: nanyang@hbut.edu.cn; Tel.: +86-27-88015996
}

Received: 23 August 2019; Accepted: 25 October 2019; Published: 25 October 2019

\begin{abstract}
In this study, peanut, sesame, and rapeseed oil bodies (OBs) were extracted by the aqueous medium method. The surface protein composition, microstructure, average particle size $d_{4,3}, \zeta$-potential of the extracted OBs in aqueous emulsion were characterized. The stability of the $\mathrm{OB}$ emulsions was investigated. It was found that different $\mathrm{OB}$ emulsions contained different types and contents of endogenous and exogenous proteins. Aggregation at low $\mathrm{pHs}(<6)$ and creaming at high pHs (7 and 8 ) both occurred for all of three OB emulsions. Sodium alginate (ALG) was used to solve the instability of OB emulsions under different conditions-low concentration of ALG improved the stability of $\mathrm{OB}$ emulsions below and near the isoelectric point of the OBs, through electrostatic interaction. While a high concentration of ALG improved the OB emulsion stability through the viscosity effect at $\mathrm{pH}$ 7. The OB emulsions stabilized by ALG were salt-tolerant and freeze-thaw resistant.
\end{abstract}

Keywords: oil bodies; emulsion stability; sodium alginate; protein-polysaccharide interaction; viscosity

\section{Introduction}

Oil bodies (OBs) are natural droplets with a core of liquid triacylglycerols (TAGs) surrounded by a monolayer membrane of phospholipids embedded with $\mathrm{OB}$ endogenous proteins [1,2]. These surface proteins include mainly oleosin $(15 \sim 25 \mathrm{kDa})$, caleosin $(27 \sim 30 \mathrm{kDa})$, and steroleosin $(\sim 40 \mathrm{kDa})$. Oleosin and caleosin are the main structural proteins consisting of a central hydrophobic domain anchored inside the TAG, and a hydrophilic N-terminal and a C-terminal facing the cytoplasm [3-7]. Steroleosin is not considered to contribute to the structure stability of OBs, although it comprises a similar structure as caleosin, e.g., a shorter hydrophobic sequence and longer hydrophilic domains as compared to oleosin [8-11]. OBs can be obtained by aqueous extraction, through which the produced OBs are in the form of aqueous creams or emulsions. On one hand, the OB droplets are naturally emulsified without the addition of other surfactants or chemicals. On the other hand, natural nutrients such as fat-soluble vitamin $\mathrm{E}$, and unsaturated fatty acids which are the naturally predominant components of the TAG molecules at the sn-2 position, can be completely preserved in such extracted natural OBs [4,11-14]. Moreover, the natural OB emulsion has a physical and chemical stability against external environmental perturbation, such as mechanical stresses, temperature, and oxidation $[8,15]$, which is attributed to the protection by the phospholipid-protein membrane formed by the endogenous proteins 
and the outer layer stabilization by the exogenous proteins in the OB emulsion. The endogenous proteins on the surface of the OBs provide a certain charge and steric hindrance, resulting in a repulsive force that is relatively weak between the OB droplets and, thus, maintains the stability of the OB emulsion [16,17]. The exogenous proteins provide a second layer protection on the OB droplets by increasing the repulsive force between droplets and by the steric effect [18]. Therefore, the OBs and their aqueous emulsions have received extensive attention, and have the potential for developing beverages [19], edible films and coatings [20], and salad dressings, in the field of food industry [21].

In practical applications and development of food products using natural OBs, the stability of $\mathrm{OB}$ emulsions is affected by the processing conditions and the external environments, such as $\mathrm{pH}$, freeze-thaw cycle, or salt ion strength, which might cause aggregation, coalescence, and demulsification [22,23]. The physical instability of $\mathrm{OB}$ emulsions can be improved by adding surfactants or biopolymers $[16,18,21,23-25]$. The surfactant can adsorb on the OB membrane or displace a surface protein, forming a denser membrane composed of surfactant and protein-phospholipids. In recent years, polysaccharides such as xanthan gum [18], gum arabic [24], carrageenan [23], and pectin [16,26] were used to improve the stability of OB emulsions. The charged polysaccharide can interact with the OB surface proteins, forming a second layer by improving the spatial repulsive force, reducing depletion flocculation, and improving the OB droplet stability [27]. As a linear anionic polysaccharide, sodium alginate (ALG) has unique functions, such as slowing down the absorption of fatty acids and bile salts, thus reducing the content of serum, cholesterol, blood triglycerides, and blood glucose in human body [28]. ALG can be dissolved and mixed at room temperature without heating, and can build up viscosity with a relatively low concentration. Therefore, the use of ALG to stabilize OB emulsion is highly significant and promising in the food industry. In a previous study, we stabilized the soybean OB emulsion by using ALG in different environments ( $\mathrm{pH}$, salt, and freeze-thaw cycle), and found that ALG can be adsorbed onto the surface of OB droplets, preventing OB aggregation at low pHs [29].

However, depending on the sources and extraction methods, the composition and amount of the surface proteins, as well as the exogenous proteins of diverse OBs might vary, therefore, affecting the properties and application of the OBs [1,8,29-33]. For example, it was observed that small maize germ OBs exhibited high stability against coalescence as they flocculated with other neighboring oil droplets in the aqueous environment, while larger-sized OBs, e.g., from other origins, might not be able to resist the mechanical stresses arising from depletion flocculation, thus, leading to coalescence and hence emulsion destabilization [18].

In this study, we extracted peanut, sesame, and rapeseed OB creams by the aqueous medium method. The moisture, fat, and protein contents of the extracted OB cream were analyzed. The surface protein composition, microstructure, average particle size $d_{4,3}, \zeta$-potential, and stability of the OB emulsions were measured. Compared with the soybean OB in the previous study [29], the peanut, sesame, and rapeseed OB creams were composed of more than 55\% fat, and their emulsions not only showed aggregation phenomenon near the isoelectric point (IEP), but also showed a creaming phenomenon at high $\mathrm{pHs}$. In addition, the peanut, sesame, and rapeseed OB emulsions were severely affected by salt ions, as compared to the soybean OB emulsion. ALG was used to tackle the problem of the instability of the $\mathrm{OB}$ emulsions at different $\mathrm{pH}$ values by changing the concentration of ALG. The concentration of the ALG under different conditions was optimized; the mechanism is discussed herein. The salt and heat resistance of the OB emulsions stabilized by the optimized ALG concentration were also evaluated. Thus, this study broadened the range of applications for diverse OBs under different conditions. 


\section{Results and Discussion}

\subsection{OB Characteristics}

The main chemical compositions of the three OB creams (peanut, sesame, and rapeseed) extracted using the aqueous media method are listed in Table 1. For comparison, the table also provides the compositions of the soybean OB cream from Su et al. [29]. Among the three OBs (peanut, sesame, and rapeseed), the average particle size of the sesame $\mathrm{OB}$ was the largest, and that of the rapeseed OB was the smallest. Their particle size distribution is shown in Figure 1a. The protein content of the rapeseed $\mathrm{OB}$ was the highest, and that of the sesame OB cream was the lowest, in contrast to the order of the fat content. Therefore, the rapeseed OB had the highest protein-to-fat ratio, while the sesame OB had the lowest among the three OBs. However, both the protein content and the protein-to-fat ratio for all three OBs were lower than those of the soybean $\mathrm{OB}$, as listed in Table 1.

The $\zeta$-potential of the peanut, sesame, and rapeseed OB droplets in emulsion at different $\mathrm{pHs}$ are shown in Figure 1b. It can be seen that the $\zeta$-potential of the peanut, sesame, and rapeseed OBs all decreased from $\mathrm{pH} 3$ to $\mathrm{pH} 8$, and the IEPs were about $\mathrm{pH} 4.6,4.0$, and 4.9, respectively.

The surface protein species of the three extracted OBs were characterized by sodium dodecyl sulfate polyacrylamide gel electrophoresis (SDS-PAGE) (Figure 1c-e). The protein bands of the peanut $\mathrm{OB}$ are 18, 21, 25, 30, 40, 54, and $66 \mathrm{kDa}$, and larger Mws (Figure 1c). Among them, proteins of $18 \mathrm{kDa}$ and $21 \mathrm{kDa}$ are the endogenous proteins of the peanut oleosins, $25 \mathrm{kDa}$ and $30 \mathrm{kDa}$ are the caleosins, and proteins of $40 \mathrm{kDa}$ are the steroleosins [24,34]. The other proteins with higher Mws (54 and $66 \mathrm{kDa})$ are the exogenous proteins [34,35]. The protein bands of the sesame OB are 14, 16, 21, 24, and $26 \mathrm{kDa}$ (Figure 1d). All of which are the sesame oleosins (Mw of 14, 16, and $21 \mathrm{kDa}$ ), and the sesame caleosins (Mw of 24 and $26 \mathrm{kDa}$ ) [34,36], indicating that the exogenous proteins were almost completely removed. In Figure 1e, the proteins of the rapeseed OB are the endogenous oleosins with $\mathrm{Mw}$ of $17 \mathrm{kDa}$, caleosins with Mws of 25 and $30 \mathrm{kDa}$, and exogenous proteins of higher Mws of 54 and $88 \mathrm{kDa}[34,37,38]$. These results suggested that the OBs carried different endogenous and exogenous proteins. First, compared to the peanut and rapeseed $\mathrm{OB}$, the sesame OB had substantially no exogenous proteins. Second, even for the same type of endogenous proteins, their Mw varied [32]. These differences were mainly due to the fact that the endogenous and exogenous proteins of different seed OBs were differently influenced by the same extraction conditions and cleaning agents $[25,34]$. The differences in the type and content of endogenous and exogenous proteins influence the stability of the OB emulsions since the structures such as the amino acid sequence and the number of the proteins are different. Therefore, we further investigated the stability of these OB emulsions at different conditions and used ALG to solve the stability problem in the following sections.

Table 1. Chemical compositions of the extracted oil bodies (OBs) creams.

\begin{tabular}{cccccc}
\hline & $\boldsymbol{d}_{4,3}(\boldsymbol{\mu m})$ & Fat $(\boldsymbol{w t} . \%)$ & Protein $\mathbf{( w t . \% )}$ & Moisture $(\boldsymbol{w t} . \%)$ & Protein/Fat \\
\hline Soybean [29] & $0.54 \pm 0.01$ & $29.40 \pm 1.00$ & $3.00 \pm 0.20$ & $53.60 \pm 2.30$ & $0.10 \pm 0.01$ \\
Peanut & $2.31 \pm 0.12$ & $72.91 \pm 1.03$ & $1.16 \pm 0.01$ & $22.72 \pm 0.14$ & $0.02 \pm 0.01$ \\
Sesame & $3.65 \pm 0.01$ & $80.56 \pm 0.80$ & $0.95 \pm 0.01$ & $17.66 \pm 0.19$ & $0.01 \pm 0.01$ \\
Rapeseed & $1.05 \pm 0.01$ & $55.34 \pm 0.75$ & $2.95 \pm 0.04$ & $37.38 \pm 0.26$ & $0.05 \pm 0.01$ \\
\hline
\end{tabular}


a

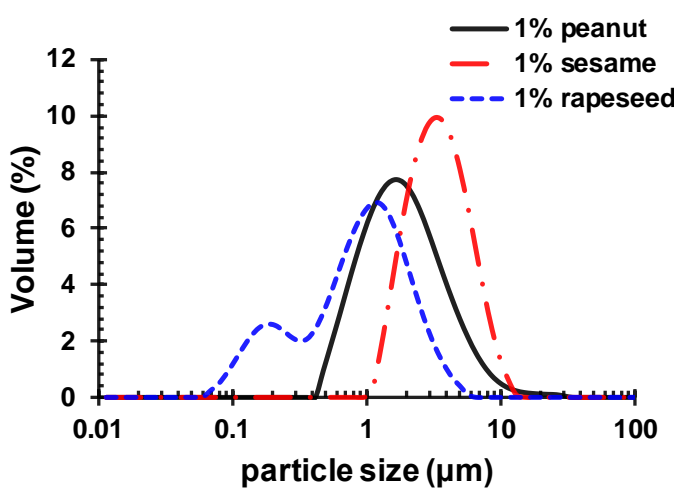

c

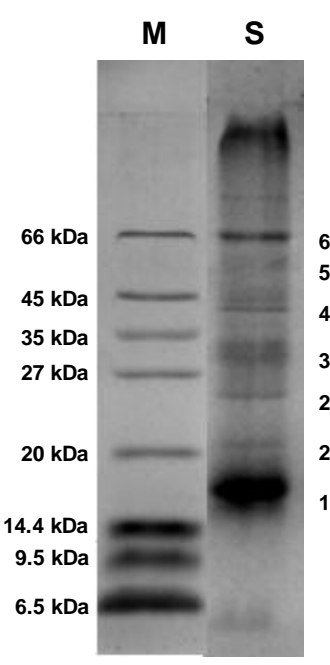

d

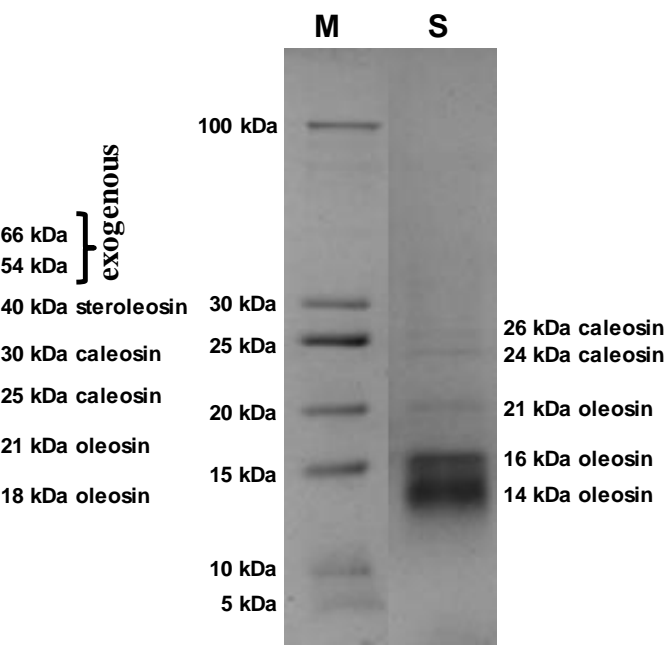

b

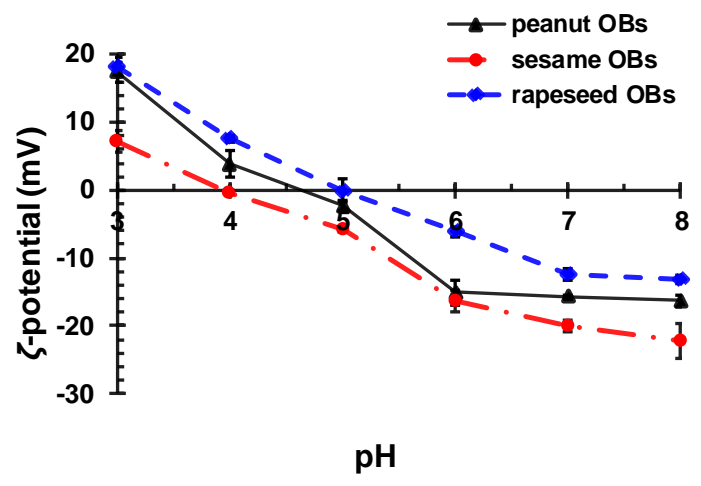

e

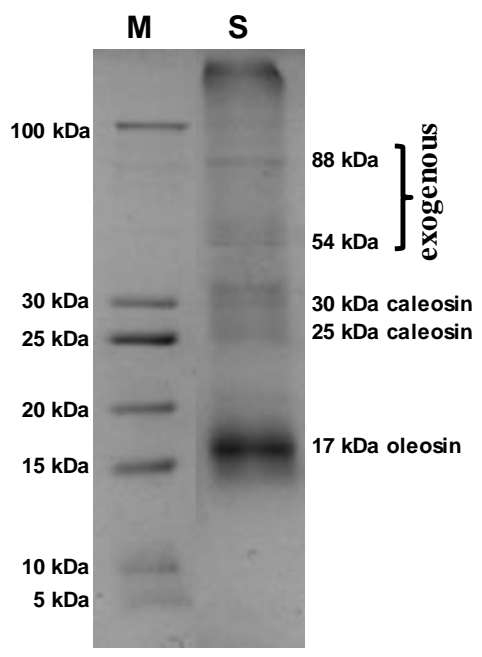

Figure 1. (a) The particle size distribution at $\mathrm{pH} 7,(\mathbf{b})$ the $\zeta$-potential at various $\mathrm{pHs}$ of the three oil body (OB) emulsions (1 wt.\%), and SDS-PAGE of the (c) peanut, (d) sesame, and (e) rapeseed OB surface proteins. Column $\mathrm{M}$-molecular mass markers; and column S-proteins on the surface of the OBs.

\subsection{Influence of $p H$ on the Creaming Stability of $O B$ Emulsions}

The effect of different pHs (from 3 to 8) on the stability of different $\mathrm{OB}$ emulsions was first examined. Photomicrographs of the $\mathrm{OB}$ emulsions at different $\mathrm{pHs}$ are displayed in Figure $2 \mathrm{a}-\mathrm{c}$. At $\mathrm{pH}$ 3, the peanut and rapeseed $\mathrm{OB}$ emulsions were well-dispersed, although the sesame $\mathrm{OB}$ emulsion showed a slight aggregation. At pH 4-6, all three OB emulsions showed a certain degree of aggregations. The sesame OBs were likely to have the largest aggregation among the three OBs. At pH 7 and 8, all OBs were well-dispersed in the emulsion, as they were strongly negatively charged. After storage for 7 days at room temperature, all three OB emulsions showed a creaming phenomenon at all pHs, as shown in Figure $2 \mathrm{~d}-\mathrm{f}$. The creaming speed of the sesame OB emulsion was the fastest. The emulsions were extremely unstable near their IEP, which was probably due to the fact that the $\zeta$-potential was low and the electric repulsion between the OB droplets was weak [22,29,39,40]. The OBs were prone to aggregate and then speeded up the rate of creaming. At a pH away from the IEP, the OB emulsions could maintain a certain stability due to the electrostatic repulsion [16] and steric hindrance of the surface proteins [4]. However, a completely stable OB emulsion over storage could not be obtained by using the extraction method employed in this study. 
a $1 \mathrm{wt} \%$ peanut $\mathrm{OB}$

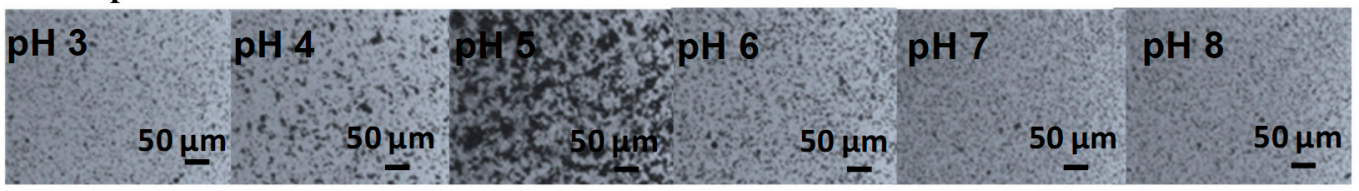

b $1 \mathrm{wt} \%$ sesame OB

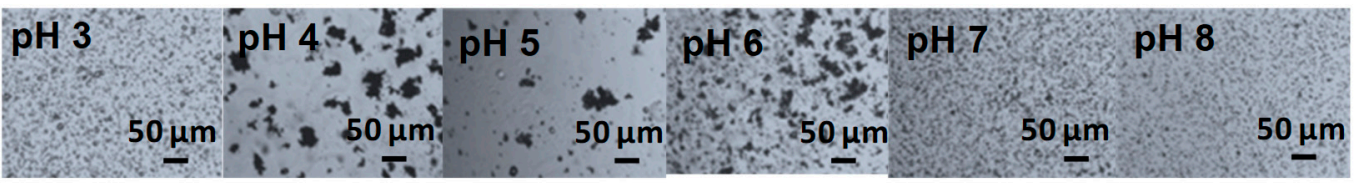

c $1 \mathrm{wt} \%$ rapeseed $\mathrm{OB}$

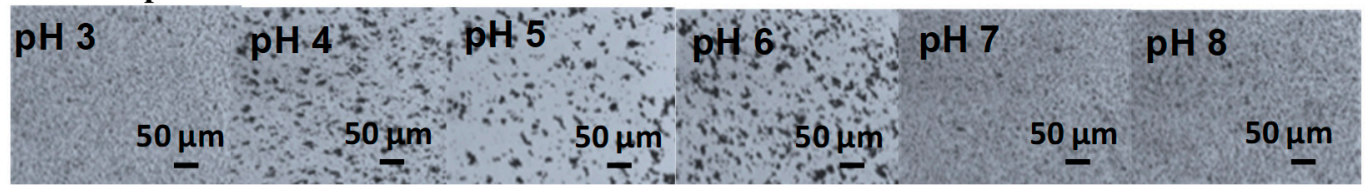

d

$1 \mathrm{wt} \%$ peanut $\mathrm{OB}$

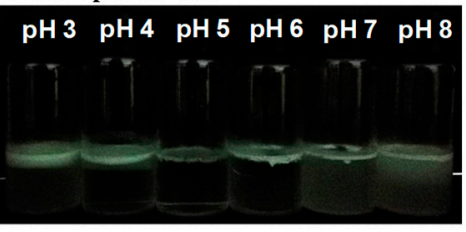

e

$1 \mathrm{wt} \%$ sesame OB

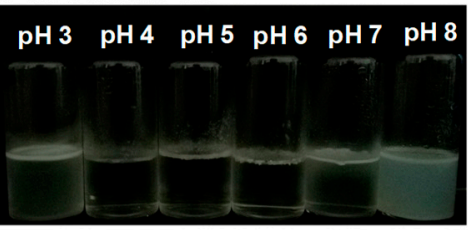

f

$1 \mathrm{wt} \%$ rapeseed $\mathrm{OB}$

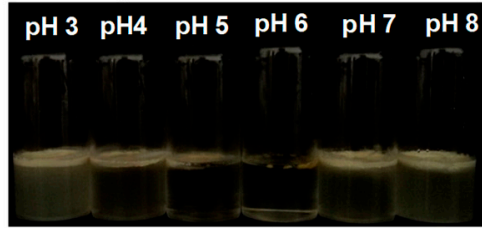

Figure 2. $\mathrm{pH}$ effect on the microstructure and creaming stability of $\mathrm{OB}$ emulsions during storage-(a,d) peanut, $(\mathbf{b}, \mathbf{e})$ sesame, and $(\mathbf{c}, \mathbf{f})$ rapeseed OBs. The OB creams were dispersed in $50 \mathrm{mmol} / \mathrm{L}$ sodium phosphate buffer solution (PBS) to a concentration of $1 \mathrm{wt} . \%$. The creaming observation was made after storage at $22 \pm 2{ }^{\circ} \mathrm{C}$ for 7 days.

These results indicated that the stability of the $\mathrm{OB}$ emulsions was related to $\mathrm{pH}$ and was also affected by the amount of endogenous and exogenous proteins, as well as the nature of the oleosins, as has been discussed previously [40]. The contents of the endogenous and the exogenous proteins of the sesame OBs were less than that of the other two seed OBs, according to Figure 1c-e. The sesame OBs had almost no exogenous proteins and a very small amount of endogenous proteins. Thus, the amount of charges provided by the sesame OB surface proteins was lower than those of peanut and rapeseed $\mathrm{OBs}$, and the IEP of the sesame $\mathrm{OB}$ moved to the direction of a lower $\mathrm{pH}$ [40]. In addition, the primary structure of the sesame oleosins showed that the sesame oleosins had shorter hydrophilic terminals on the surface of the sesame OBs [40-42]. Therefore, the stability of the sesame OB emulsion was worse than the other two OBs, due to the insufficient electrostatic repulsion and low steric protection. In the creaming process of the $\mathrm{OB}$ emulsions, the $\mathrm{OB}$ droplets diffused and rose up to the air-water surface, causing the increase of the interfacial pressure and, thus, some OBs at air-water surface might rupture, although others remain integrated and agglomerated [43]. Therefore, aggregation and creaming of $\mathrm{OB}$ emulsions affect the processing and quality of the food products, and, should be intervened.

\subsection{Influence of ALG on $O B$ Emulsions}

The OB emulsions had the most serious aggregation and creaming near their IEP, and were also very unstable during storage where aggregation occurred when the ion concentration or temperature changed $[23,29,44]$. It has been shown that anionic polysaccharide ALG or alginate type hydrocolloids (pectin) could be adsorbed on soybean OB surface at a $\mathrm{pH}$ lower than IEP, which increased the stability of the OBs by reducing the van der Waals attraction and increasing the electrostatic repulsion $[17,29,39]$. In this work, the ALG was applied to stabilize the unstable peanut, sesame, and rapeseed OB emulsions 
at a $\mathrm{pH}$ around their IEP. First, the ALG concentrations were optimized. A pH slightly lower than the IEP of each OB emulsion was chosen to find the optimum concentration of ALG- $\mathrm{pH} 3.9$ was chosen for the sesame and peanut $\mathrm{OB}$ emulsions; $\mathrm{pH} 4.5$ was chosen for the rapeseed $\mathrm{OB}$ emulsion. The effect of ALG concentrations on the $\zeta$-potential and particle size of the three OB emulsions is shown in Figure 3 . In Figure $3 \mathrm{a}-\mathrm{b}$, at the experimental $\mathrm{pH}$ of each $\mathrm{OB}$ emulsion, as mentioned above- the $\zeta$-potential of the OB emulsions and the particle size decreased with an increasing concentration of ALG. When the ALG reached a certain concentration, the $\zeta$-potential and particle size basically reached a plateau value, which meant that the minimum concentration of ALG which could stabilize the OB emulsion was reached. The stabilized OB emulsion with this concentration of ALG had a relevant large $\zeta$-potential, and the smallest particle size, since the electrostatic repulsion between oil particles was strong enough to keep the stability of droplets against aggregation. Therefore, the optimal concentration of ALG was $0.35 \mathrm{wt} . \%$ for the peanut OB emulsion, $0.45 \mathrm{wt} . \%$ for the sesame OB emulsion, and $0.3 \mathrm{wt} . \%$ for the rapeseed $\mathrm{OB}$ emulsion (emulsions all with $1 \mathrm{wt} . \% \mathrm{OB}$ cream). The concentration of saturation adsorption of ALG was inversely related to the IEP of different OBs, which was determined by the structure of the oleosins [40].

a

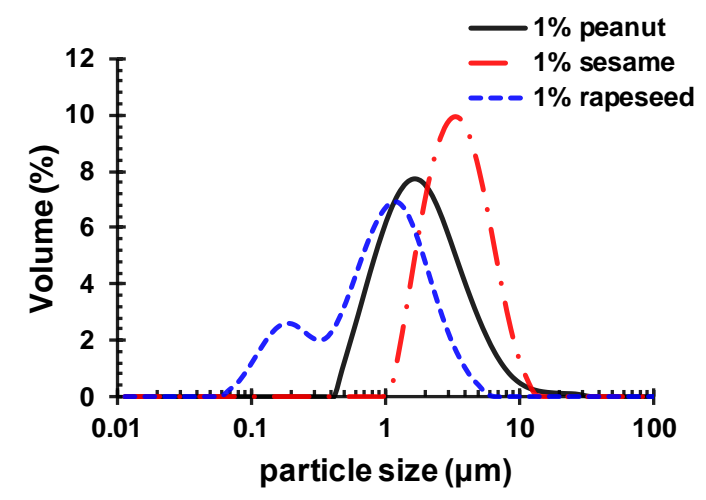

b

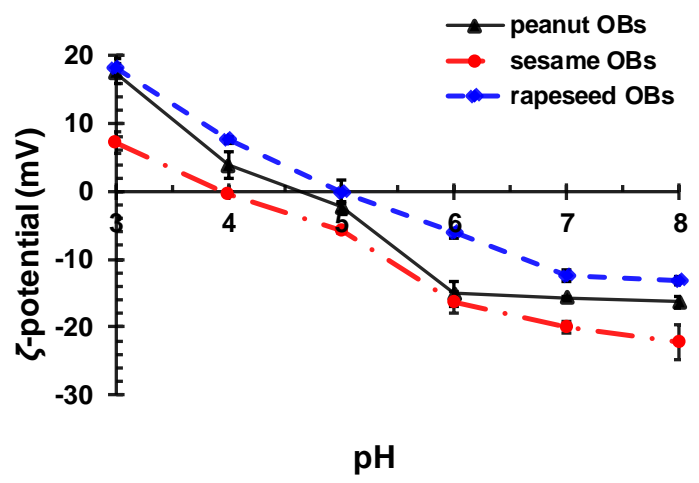

Figure 3. (a) The $\zeta$-potential and (b) particle size $\left(d_{4,3}\right)$ of the three OBs coated by different concentrations of sodium alginate (ALG) at a $\mathrm{pH}$ of about 4 (pH 3.9 for the sesame and peanut emulsions; $\mathrm{pH} 4.5$ for the rapeseed emulsion).

The creaming stability of the OB emulsions with the optimum concentration of ALG was then investigated, and the results are displayed in Figure $4 \mathrm{a}-\mathrm{c}$. It can be seen that at a $\mathrm{pH}$ close to the IEP (pH 3-6), the creaming stability of the three OB emulsions was relatively good, and much improved compared to that in the absence of ALG (comparing Figure $4 a-c$ with Figure $2 d-f$ ), suggesting that ALG can effectively balance the charge between the surface proteins of OBs, and further appropriately increase the repulsive force between OB droplets. Therefore, the OB can exist stably against aggregation at these $\mathrm{pHs}$ in the emulsion.

a

1 wt\% peanut $\mathrm{OBs}+0.35 \mathrm{wt} \%$ ALG pH 3 pH 4 pH 5 pH 6 pH 7 pH 8 b

1 wt $\%$ sesame OBs +0.45 wt\% ALG $\begin{array}{llllll}\text { pH } 3 & \text { pH } 4 & \text { pH5 } & \text { pH } 6 & \text { pH } 7 & \text { pH } 8\end{array}$ c

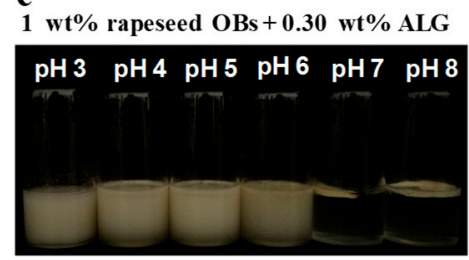

Figure 4. $\mathrm{pH}$ effect on the creaming stability of ALG-coated OB emulsions (a) peanut (1 wt.\% OB and 0.35 wt. $\%$ ALG), (b) sesame (1 wt.\% OB and 0.45 wt. $\%$ ALG), and (c) rapeseed (1 wt. $\%$ OB and 0.30 wt. $\%$ ALG). The OBs were dispersed in $50 \mathrm{mmol} / \mathrm{L}$ PBS. The creaming observation was made after storage at $22 \pm 2{ }^{\circ} \mathrm{C}$ for 7 days. 
However, the creaming phenomenon for all of the three OB emulsions still markedly occurred at pH 7 and 8, as shown in Figure 4a-c. Conversely, in the previous study, soybean OB emulsion stabilized by 0.35 wt.\% ALG at pH 7 and 8 could evenly disperse and the creaming phenomenon did not occur [29]. As mentioned above, the creaming and destabilization of the OB emulsion was related to the diffusion and exposure of the OBs to the water-air-interface $[40,43]$. There might be several reasons for the creaming stability at $\mathrm{pH} 7$ and 8 for the soybean OBs with low concentration ALG. First, the soybean $\mathrm{OB}$ emulsions contained more proteins on the OB surfaces, with the structure proteins of oleosin and caleosin being rich in content, which led to a better stability than the other three OB emulsions studied here [4,21]. Furthermore, the soybean OBs had the smallest particles size among the four OBs (Table 1), which slowed the creaming speed of the oil droplets in the emulsion during storage. Therefore, a low concentration of ALG could stabilize the soybean OB emulsion. In the present study, the droplet sizes in the sesame or peanut OB emulsions $(2.31 \pm 0.12 \mu \mathrm{m}$ or $3.65 \pm 0.01 \mu \mathrm{m}$, respectively as shown in Figure 1a) were much larger than that of the soybean OBs (about $0.54 \pm 0.01 \mu \mathrm{m}$ ), therefore, the creaming speed was probably faster. For the rapeseed OBs, although their droplet sizes were also small, they had less oleosin and caleosin on the surface than the soybean OBs, and the surface charge was also low at $\mathrm{pH} 7$, resulting in a smaller repulsive force or steric hindrance between the OBs and, thus, it was easier for the OBs to aggregate and float up. Therefore, a low concentration of ALG could not stabilize all three $\mathrm{OB}$ emulsions at $\mathrm{pH} 7$ and 8 in the present study.

\subsection{Influence of $A L G$ on the Creaming Stability of $O B$ Emulsions at $p H 7$}

In order to stabilize the $\mathrm{OB}$ emulsion at $\mathrm{pH} 7$ and 8, and slow down the creaming phenomenon, the concentration of the ALG added to the OB emulsions was increased. The stability of the OB emulsions with different concentrations of ALG under neutral conditions after 7 days of storage was analyzed, and the results are displayed in Figure 5a-d. When the ALG concentration was 0-0.9 wt.\%, the OB emulsion showed obvious creaming, that is, the OBs floated up, resulting in a cream layer on the top of the emulsion and a serum layer at the bottom, as shown in the " $0 \%$ " sample on the left in Figure 5a-c (data for other ALG concentration sample are shown in Figure S1a-c, Supplementary Materials). The creaming indices for the cream layer and the serum layer of the OB emulsions, as defined in Section 3.5, were high in these samples (Figure 5d). As the concentration of ALG increased, the creaming of OB emulsions was gradually slowed down, and both the serum and creaming indices were reduced. When the ALG concentration reached $1.2 \mathrm{wt} \%$, no creaming phenomenon was observed in the sesame OB emulsion. When the ALG concentration reached $1.5 \mathrm{wt} . \%$, the creaming phenomenon of the peanut and rapeseed OB emulsions did not occur.

To understand the mechanism of ALG stabilizing OB emulsions, Figure $6 a-c$ show the viscosity of the pure $\mathrm{OB}$ emulsion at $\mathrm{pH} 7$ and the $\mathrm{OB}$ emulsions with different concentrations of ALG as a function of the shear rate. The results showed that all three $1 \mathrm{wt}$.\% of pure OB emulsions exhibited shear thinning characteristics within the shear rate range examined. However, when the shear rate was between 10-100 s ${ }^{-1}$ the viscosity of these emulsions had stable values, which were about $2-4 \mathrm{mPa} \cdot \mathrm{s}$. When the ALG concentration increased to the optimal concentration for stabilizing the emulsions at around $\mathrm{pH} 4$, which was $0.35 \mathrm{wt} . \%, 0.45 \mathrm{wt} . \%$, and $0.3 \mathrm{wt} \%$ ALG for the peanut, sesame, and rapeseed emulsions, respectively, as discussed in Section 2.3, the viscosities of the OB-ALG emulsion systems were increased by about 4-7 folds higher than each pure OB emulsion between $10 \mathrm{~s}^{-1}$ and $100 \mathrm{~s}^{-1}$. Whereas, when the ALG concentration was increased to $1.2 \mathrm{wt} . \%$ for the sesame OB emulsion and $1.5 \mathrm{wt}$ \% for the peanut and rapeseed $\mathrm{OB}$ emulsions, the viscosities of the OB emulsions were significantly increased, e.g., the viscosity of each was about 200-700 mPa.s between $10 \mathrm{~s}^{-1}$ and $100 \mathrm{~s}^{-1}$, which was more than 100 times higher than the pure OB emulsions. According to Stokes formula [45], the increase of viscosity could increase the drag force exerted on the droplets and reduce their creaming rates in the emulsion. Meanwhile, the $\zeta$-potential of low concentration ALG and high concentration ALG stabilized OB emulsion were measured (Figure S2, Supplementary Materials). The OB emulsions with different ALG concentrations (0.30 wt.\%, 0.35 wt. \%, 0.45 wt. \%1.20 wt.\%, and 1.50 wt.\%) showed 
similar $\zeta$-potential at $\mathrm{pH}$ 7. Therefore, we believed it was the viscosity effect that effectively controlled the creaming phenomenon of the $\mathrm{OB}$ emulsions at $\mathrm{pH} 7$ and 8, since the increase in the concentration of ALG increased the emulsion viscosity. The addition of ALG at a lower concentration did not solve the creaming phenomenon of the $\mathrm{OB}$ emulsions at $\mathrm{pH} 7$, since the viscosity of each system was still not high enough to slow down the creaming of OB droplets, whereas the high viscosity of the high ALG concentration successfully slowed down the movement of the OBs.
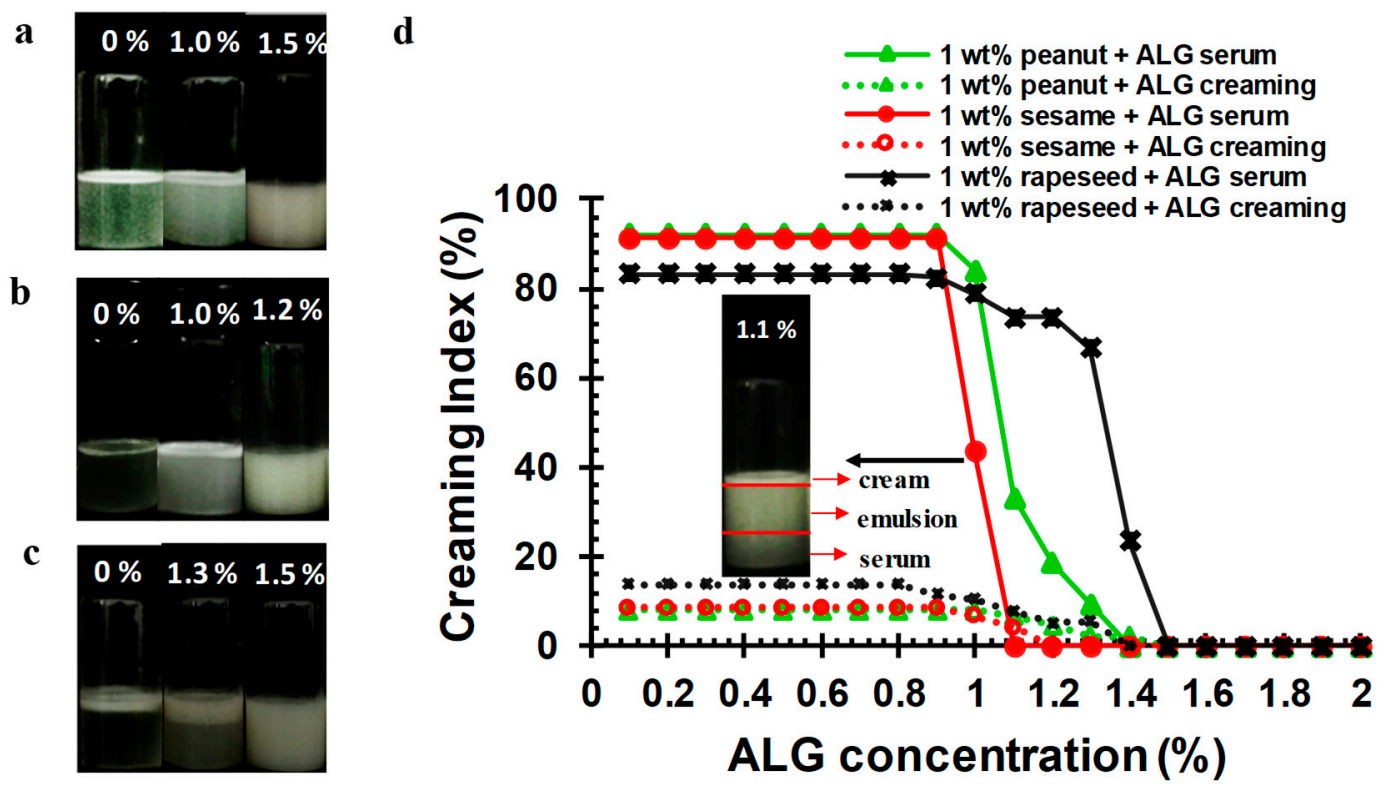

Figure 5. The creaming stability of (a) peanut, (b) sesame, (c) rapeseed emulsions and the creaming index (d) of the three OB emulsions stabilized by different concentrations of ALG at pH 7. The percentage concentrations in Figure a, b, c represent the concentration of ALG. The creaming investigation was made after storage for 7 days at $22 \pm 2{ }^{\circ} \mathrm{C}$.

$\mathbf{a}$

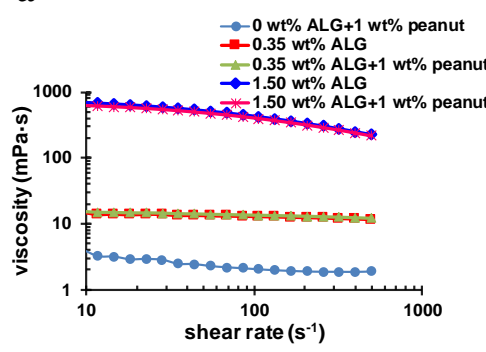

b

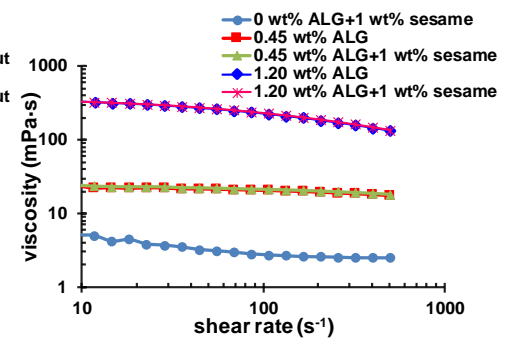

c

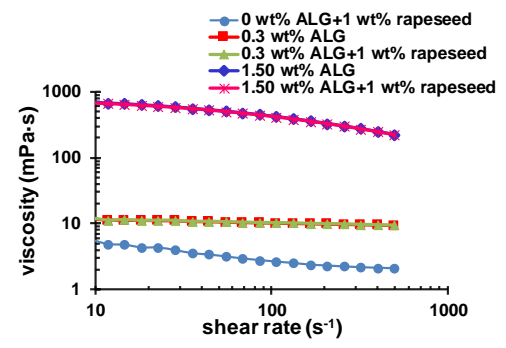

Figure 6. The viscosity of (a) peanut, (b) sesame, and (c) rapeseed OB emulsions in the presence of ALG with different concentration as indicated (at $\mathrm{pH}$ 7).

\subsection{Influence of Salt on the Stability of $O B$ Emulsions}

During the food processing, the concentration of salt ions could influence the conformation of the surface proteins and the exogenous proteins of OBs, thus, affecting the stability of OB emulsions. Therefore, the stability of the $\mathrm{OB}$ emulsion under different $\mathrm{NaCl}$ concentrations was investigated at different $\mathrm{pHs}$ ( $\mathrm{pH} 4$ and 7, were selected as the typical acidic and neutral conditions). The surface charge and particle size of the different $\mathrm{OB}$ emulsions with varying $\mathrm{NaCl}$ concentrations are shown in Figures $7 \mathrm{a}-\mathrm{c}$ and $8 \mathrm{a}-\mathrm{c}$, respectively. It could be seen that the $\zeta$-potential of the pure peanut and sesame $\mathrm{OB}$ emulsion were between $-2 \mathrm{mV}$ and $2 \mathrm{mV}$ at $\mathrm{pH} 4$, while the $\zeta$-potential of the rapeseed $\mathrm{OB}$ emulsion at $\mathrm{pH} 4$ was about $9 \mathrm{mV}$. Their $\zeta$-potentials did not change much with the increase of salt ion concentration (Figure $7 \mathrm{a}-\mathrm{c}$ ). Iwanaga et al. mentioned similar results in their studies on the 
influence of $\mathrm{NaCl}$ on OBs [22]. They attributed the constancy of $\zeta$-potential with the increase of salt concentration to the presence of endogenous salt or the charge regulation effect of the OBs. When exogenous salt $(\mathrm{NaCl})$ was added to the $\mathrm{OB}$ emulsion system, there was an electrostatic screening effect. However, the addition of exogenous monovalent cations $\left(\mathrm{Na}^{+}\right)$might partially displace any divalent cations $\left(\mathrm{Mg}^{2+}\right.$ or $\left.\mathrm{Ca}^{2+}\right)$ associated with the anionic $\mathrm{OB}$ surface, thereby, counterbalancing the expected decrease in negative charge and weakening the electrostatic screening effect, such that the expected decrease of $\zeta$-potential would be counterbalanced. Since the charges on the surface of the particles at $\mathrm{pH} 4$ are still low, the OBs tend to aggregate to larger particles to a certain extent, as indicated in Figure $8 \mathrm{a}-\mathrm{c}$. The particle size change of the rapeseed $\mathrm{OB}$ emulsion was particularly obvious, as its particle size increased from $7.8 \mu \mathrm{m}(0 \mathrm{mmol} / \mathrm{L} \mathrm{NaCl})$ to $12.3 \mu \mathrm{m}(250 \mathrm{mmol} / \mathrm{L} \mathrm{NaCl})$, as displayed in Figure 8c, which was about a 57\% increase. However, the particle size of the peanut and sesame $\mathrm{OB}$ emulsions did not change obviously, since $\mathrm{pH} 4$ was close to the IEP of the peanut or the sesame $\mathrm{OB}$ emulsion, at which the OBs aggregated more seriously than the rapeseed OBs, as shown by the large particle size in Figure $8 \mathrm{a}-\mathrm{b}$ and the microstructure in Figure S3a-b (Supplementary Materials). Therefore, the electrostatic screening effect and charge regulation did not obviously affect the particle size of the peanut and the sesame OB emulsions.
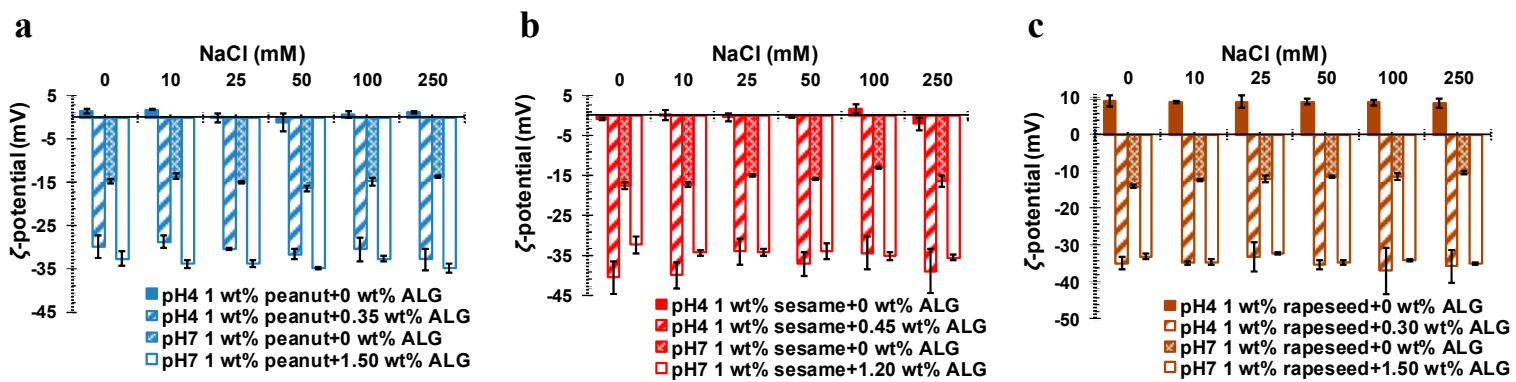

Figure 7. Salt effect on $\zeta$-potential of pure and ALG stabilized OB emulsions at different pHs as indicated: (a) peanut, (b) sesame, and (c) rapeseed. The OBs were dispersed in $50 \mathrm{mmol} / \mathrm{L}$ PBS.

a

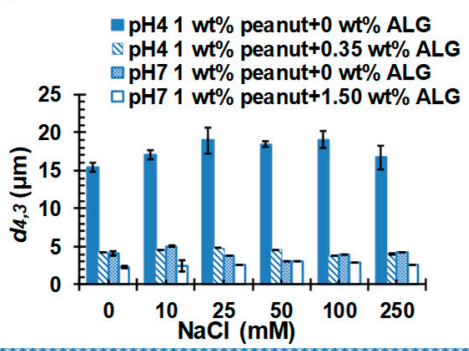

b

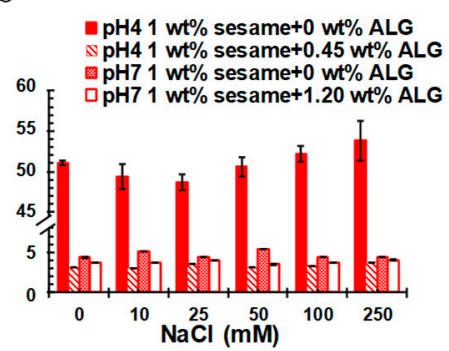

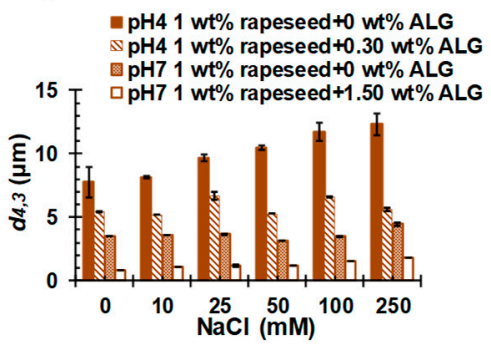

Figure 8. Salt effect on mean particle diameter $\left(d_{4,3}\right)$ of pure and ALG-stabilized OB emulsions at different $\mathrm{pHs}$ as indicated-(a) peanut, (b) sesame, and (c) rapeseed. The OBs were dispersed in $50 \mathrm{mmol} / \mathrm{L}$ PBS.

When ALG was used to stabilize the $\mathrm{OB}$ emulsions at $\mathrm{pH} 4$, as shown in Figure $7 \mathrm{a}-\mathrm{c}$, the $\zeta$-potential of the three $\mathrm{OB}$ emulsions became largely negative, with values of around -30 to $-40 \mathrm{mV}$, not changing significantly with the $\mathrm{NaCl}$ concentration. In contrast to the pure $\mathrm{OB}$ emulsions, the particle size decreased significantly, especially for the peanut and sesame OB emulsions with ALG (Figure 8a-c). Additionally, the particles size for each OB-ALG emulsion did not change with the $\mathrm{NaCl}$ concentration, indicating that the emulsions were dispersed uniformly and were stable against $\mathrm{NaCl}$.

The stability of the OB emulsions, with and without ALG, at different salt ion concentrations at $\mathrm{pH} 7$ was also measured. The results are displayed in Figures $7 \mathrm{a}-\mathrm{c}$ and $8 \mathrm{a}-\mathrm{c}$. The $\zeta$-potential of the pure peanut and sesame $\mathrm{OB}$ emulsions were about $-10 \mathrm{mV}$ to $-20 \mathrm{mV}$, without any significant variation, while $\zeta$-potential of the rapeseed $\mathrm{OB}$ emulsion showed an upward trend from $-13.93 \mathrm{mV}$ 
$(0 \mathrm{mmol} / \mathrm{L} \mathrm{NaCl})$ to $-10.27 \mathrm{mV}(250 \mathrm{mmol} / \mathrm{L} \mathrm{NaCl})$. In Figure $8 \mathrm{a}-\mathrm{c}$, with an increase of the $\mathrm{NaCl}$ concentration, the particle size of the peanut $\mathrm{OB}$ emulsion was around 3-5 $\mu \mathrm{m}$, and that of the sesame OB emulsion was around 4-5 $4 \mathrm{~m}$, implying no obvious change. The peanut and sesame OB emulsions were rich in structural proteins. The particle size of the rapeseed OB emulsion increased a little as the $\mathrm{NaCl}$ concentration increased, probably also due to the electrostatic screening effect caused by the addition of $\mathrm{Na}^{+}$. At this $\mathrm{pH}(7)$, when a high concentration of ALG was added to each of the OB emulsions, as we optimized in Section 2.4, all ALG-stabilized OB emulsions had an enlarged charge density (Figure 7a-c) and a decreased particle size (Figure 8a-c), which did not change markedly with an increase in $\mathrm{NaCl}$ concentration. Therefore, a high concentration of ALG could also improve the stability of the $\mathrm{OB}$ emulsion against the salt ions.

\subsection{Influence of Freeze-Thaw Cycling and Thermal Treatment on the Stability of OB Emulsions}

The effect of freeze-thaw cycling on the stability of the OB emulsions was also investigated. Similarly, the freeze-thaw stability under acidic and neutral conditions was examined, in terms of particle size, microstructure, and creaming stability. As can be seen from Figure $9 \mathrm{a}-\mathrm{c}$, the particle size of the pure $\mathrm{OB}$ emulsions increased with the increase of the number of freeze-thaw cycles at $\mathrm{pH} 4$, especially for the peanut and sesame OB emulsions. This was mainly because the three OB emulsions were in an unstable state at $\mathrm{pH} 4$, and the oil droplets coalesced after freezing and thawing, forming large particle droplets. The creaming index for the serum layer of the freeze-thawed emulsion at pH 4 (Figure 10a-c), was also significantly high, indicating the instability of the emulsion against freeze-thaw cycling.

a

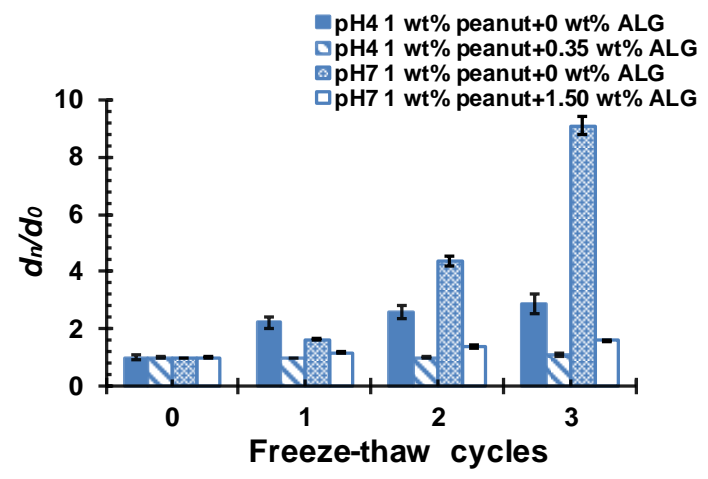

C

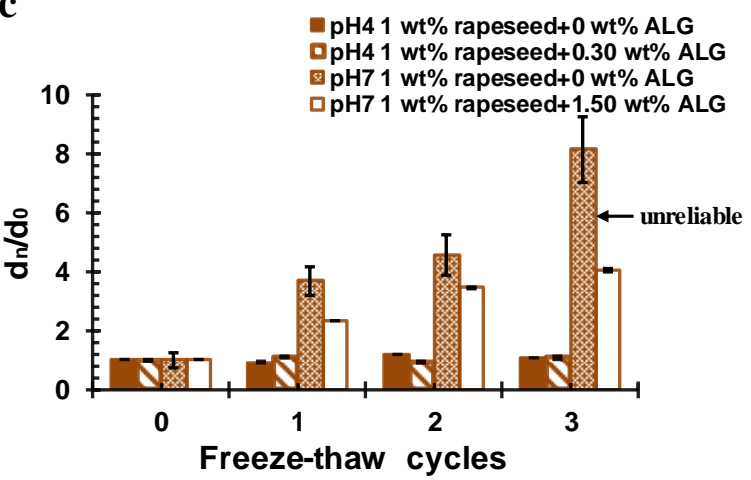

b

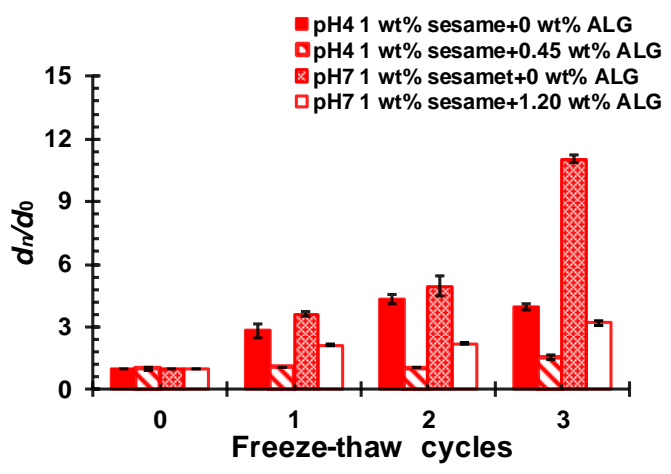

d
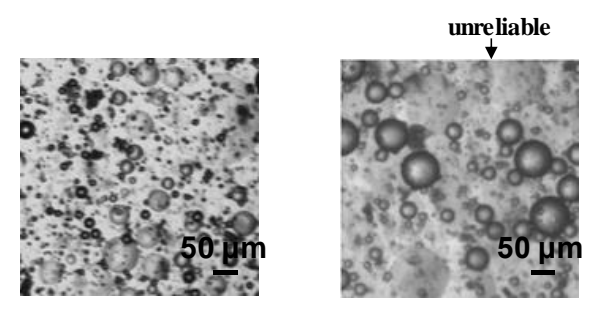

2 freeze-thaw cycles 3 freeze-thaw cycles

Figure 9. Effect of the freezing-thawing cycle on relative particle diameter $\left(d_{n} / d_{0}\right)$ of pure and ALG-stabilized OB emulsions at different $\mathrm{pHs}$, as indicated-(a) peanut, (b) sesame, and (c) rapeseed, (d) effect of the freezing-thawing cycles on the microstructure of rapeseed OB emulsions. The OBs were dispersed in $50 \mathrm{mmol} / \mathrm{L}$ PBS. $d_{n}$ was the droplet size after ' $\mathrm{n}$ ' freeze-thaw cycles and $d_{0}$ was the droplet size before the freeze-thaw cycles. 

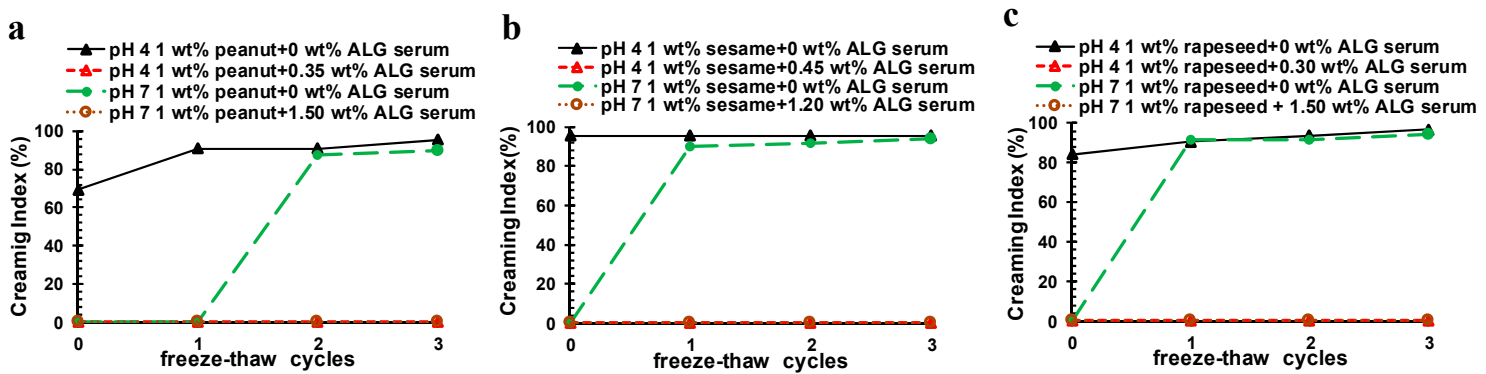

Figure 10. Effect of freezing-thawing cycle on the creaming stability of pure and ALG-stabilized OB emulsions at different $\mathrm{pHs}$, as indicated-(a) peanut, (b) sesame, and (c) rapeseed. The OBs were dispersed in $50 \mathrm{mmol} / \mathrm{L}$ PBS. The creaming index here is for the serum layer of the OB emulsions after different freezing-thawing cycles.

At $\mathrm{pH} 7$, all pure $\mathrm{OB}$ emulsions showed an even increase of particle size after freeze-thaw treatment, following obvious coalescence of oil droplets and demulsification, although the result after the third freeze-thaw cycle might be unreliable, since the coalescent oil droplets were easily attached to the sample vial. The real particles sizes were even greater than the data shown in Figure $9 \mathrm{a}-\mathrm{c}$ for pure $\mathrm{OB}$ emulsions after three times of freeze-thaw cycling at $\mathrm{pH}$ 7. The creaming index in Figure 10a-c also show a serious creaming phenomenon [44,46-48].

After addition of ALG at the optimal concentration to either $\mathrm{pH}$, the particle size of the peanut, sesame, and rapeseed $\mathrm{OB}$ emulsions all became much smaller, as compared to the pure $\mathrm{OB}$ emulsion, frozen and thawed by the same number of freeze-thaw cycling. Even after three cycles of freezing and thawing, the peanut, sesame, and rapeseed OB emulsions stabilized by ALG showed a slight increase of particle size, respectively, and the demulsification phenomenon did not occur any more. The creaming phenomenon after freezing and thawing was also controlled, and no obvious creaming occurred in these ALG-stabilized emulsions with a very low creaming index obtained in Figure 10a-c. Therefore, the addition of ALG protected the OB emulsion against the freeze-thaw cycling process, and improved the stability of the $\mathrm{OB}$ emulsions at both acidic and neutral conditions.

Effect of thermal treatment at high temperatures $\left(60,90\right.$ and $\left.120^{\circ} \mathrm{C}\right)$ on the stability of the $\mathrm{OB}$ emulsions was also investigated. The results were displayed in the Supplementary Materials. After thermal treatment at each temperature for $30 \mathrm{~min}$, the $\zeta$-potential (Figure S4, Supplementary Materials) of each $\mathrm{OB}$ emulsion did not change much compared with that after heating at $25^{\circ} \mathrm{C}$. The microstructure (Figure S5, Supplementary Materials), and particle size and its corresponding change (Figure S6, Supplementary Materials) after high temperature treatment of the three pure and ALG-stabilized OB emulsions at $\mathrm{pH} 4$ or $\mathrm{pH} 7$ are also similar to those at $25^{\circ} \mathrm{C}$. The results indicate that ALG stabilized-OB emulsions also have great stability against high temperature thermal treatment.

\section{Materials and Methods}

\subsection{Materials}

Peanuts and sesame were purchased from Shenyang Xinchang Grain Trade Co. Ltd. (Shenyang, China). Rapeseed was provided by the Institute of Oil Crops, Chinese Academy of Science. The ALG was provided by FMC BioPolymer (Drammen, Norway), which had a molecular weight (Mw) of $270 \mathrm{kDa}$ and a polydispersity index of 1.50 . Other chemicals were of analytical grade and were purchased from the Sinopharm Chemical Reagent Co. Ltd. (Shanghai, China). Ultra-pure water (LBS-RUP60, Chengdu Haokang Technology Co., Ltd., Chengdu, China) was used for the preparation of all solutions. 


\section{2. $O B$ Extraction}

OBs were extracted from plant seeds (peanut, sesame, and rapeseed) according to the method described by Su et al. [29]. Generally, the soaked seeds were blended by a commercial food processor (KS-920, Guangzhou City Electric Appliance Co., Ltd., Guangzhou, China) to obtain a homogenate of each. Then, the homogenate was filtered and the filtrate was centrifuged at a high acceleration of $10,000 \times g$, for $30 \mathrm{~min}$ at $4{ }^{\circ} \mathrm{C}$ (CR21N, Hitachi Koki Co., Ltd., Tokyo, Japan), and was washed once with urea and with Tris- $\mathrm{HCl}$ buffer solution for three times.

\subsection{Characterization of $O B$ Chemical Compositions}

The chemical compositions (the contents of fat, proteins, and moisture) of the extracted OB cream were determined according to the Association of Official Analytical Chemists (AOAC) methods [29,49]. The fat content of the OBs was determined by the Soxhlet extractor system using petroleum ether as the extraction solvent. Nitrogen content of the OBs were determined by the Kjeldahl method. The 6.25x Kjeldahl N conversion factor was used to convert the percentage of nitrogen to the protein content. The moisture content of the OBs was determined by oven drying.

The composition of the OB surface proteins was analyzed by SDS-PAGE, according to the method described by Su et al. [29].

\subsection{Preparation of $O B$ Emulsions with Different Concentrations of ALG}

The peanut, sesame, and rapeseed OB emulsions (5 wt.\%) were prepared by dispersing $5 \mathrm{~g}$ of each extracted OB cream in $95 \mathrm{~g}$ PBS ( $50 \mathrm{mmol} / \mathrm{L}, \mathrm{pH} 7)$, respectively, under stirring for $2 \mathrm{~h}$, followed by sonicating for $3 \mathrm{~min}$ (Frequency, $20 \mathrm{kHz}$; Amplitude, 40\%; Duty cycle, $1 \mathrm{~s}$ ), using a high-intensity ultrasonic probe device (VCX800, 53 Church Hill Rd. Newtown, CT, USA) [29].

ALG solution (3 wt.\%, pH 7) was prepared by dispersing the weighed powders of ALG into PBS (50 mmol/L, pH 7) under magnetic stirring for $24 \mathrm{~h}$. Then, $20 \mathrm{~mL}$ of each OB emulsions were mixed with a different amount of ALG, respectively, to achieve the desired concentration. And then the mixtures were stirred for $2 \mathrm{~h}$ at $22 \pm 2{ }^{\circ} \mathrm{C}$. Finally, the $\mathrm{pH}$ value of the OB emulsions with ALG was adjusted, using $1 \mathrm{~mol} / \mathrm{L} \mathrm{HCl}$, under magnetic stirring for another $30 \mathrm{~min}$. The samples were kept at $22 \pm 2{ }^{\circ} \mathrm{C}$ for $24 \mathrm{~h}$ before analysis.

\subsection{Particle Size, $\zeta$-Potential, Microstructure, and Emulsion Stability Measurements}

The particle size of diluted OB emulsions and OB emulsions with ALG was measured using a laser light scattering instrument (Malvern Mastersizer 2000, UK) [29]. The OBs were diluted with water to an approximate oil concentration of $0.005 \mathrm{wt} . \%$. The refractive index used for OB was 1.47 , and that of water was 1.33 . The density of $\mathrm{OB}$ used was $0.92 \mathrm{~g} / \mathrm{cm}^{3}$. The volume-weighted mean diameter $\left(d_{4,3}=\sum n_{i} d_{i}^{4} / \sum n_{i} d_{i}^{3}\right)$ was measured and used in the following analysis, where $n_{i}$ was the number of droplets of diameter $d_{i}$.

The electric potential ( $\zeta$-potential) of the $\mathrm{OB}$ emulsion was measured by diluting the sample to an approximate oil concentration of $0.005 \mathrm{wt} \%$ (diluted with PBS) and was calculated by the electrophoretic mobility of the droplets measured, using a capillary electrophoresis cell (Zetasizer Nano ZS series, Malvern Instruments, Worcestershire, UK), expressed as the average values from triplicate measurements [29].

An Olympus microscope (Olympus IX73, Olympus Corporation, Tokyo, Japan) mounted with a scientific CMOS camera (Prime, Teledyne Photometrics, Surrey, Canada) was used to observe the microscopic morphology of the OB emulsions, which were diluted with PBS at different pHs, salt ionic strength, and after freeze-thaw cycling or high temperature thermal treatment. A small amount of each OB emulsion sample was placed on a glass slide and a cover glass was applied gently to form a thin sample layer and the slide was placed under the microscope with " $4 \times$ " and " $20 \times$ " objective for visualization. 
The creaming stability of the $\mathrm{OB}$ emulsion was evaluated at $22 \pm 2{ }^{\circ} \mathrm{C}$, according to the method of $\mathrm{Wu}$ et al. [23]. A total of $10 \mathrm{~mL}$ of each emulsion was placed in a sealed glass vial for storage. After 7-days of storage, the stability of the emulsion was indicated by the creaming indices, defined as - the creaming index of the serum layer $(\%)=$ (height of serum layer/total height of the emulsion) $\times 100 \%$, and the creaming index of the cream layer $(\%)=$ (height of cream layer/total height of the emulsion) $\times 100 \%$, respectively. The creaming stability of the emulsion was controlled or there was no creaming instability for the emulsion if its creaming index of the serum layer and that of the cream layer were both $0 \%$.

The influence of $\mathrm{pH}$, salt ionic strength, freeze-thaw cycling, and thermal treatment on pure OB emulsion and OB emulsions stabilized by ALG were examined. The emulsions were adjusted to a different $\mathrm{pH}$ ( $\mathrm{pH} 3,4,5,6,7$ and 8), using $1 \mathrm{~mol} / \mathrm{L} \mathrm{HCl}$ or $\mathrm{NaOH}$. The OB suspensions with different ionic strengths $(0-250 \mathrm{mmol} / \mathrm{L})$ were prepared by adding different ratios of the sodium phosphate buffer $(50 \mathrm{mmol} / \mathrm{L}, \mathrm{pH} 7)$ and $1 \mathrm{~mol} / \mathrm{L} \mathrm{NaCl}$. For the freeze-thaw cycling and thermal treatment, a quantity of $10 \mathrm{~mL}$ of each OB emulsions, uncoated and coated with ALG at pH 4 or pH 7, was transferred in a sealed glass bottle. This freeze-thaw cycling was repeated up to three times. These emulsions were stored at a low temperature of $-20^{\circ} \mathrm{C}$ for $22 \mathrm{~h}$, and then the suspensions were heated at $40^{\circ} \mathrm{C}$ for $2 \mathrm{~h}$. For thermal treatment, the $\mathrm{OB}$ emulsions were heated at a fixed temperature $(25,60,90$ and $120^{\circ} \mathrm{C}$ ) for $30 \mathrm{~min}$, respectively, and then the properties of the $\mathrm{OB}$ emulsions including $\zeta$-potential, particle size, and microstructure were examined after cooling them to ambient temperature $\left(25^{\circ} \mathrm{C}\right)$.

\subsection{Viscosity Measurements of $O B$ Emulsions}

The viscosity of the different OB emulsions with ALG was measured by using a HAAKE RS6000 Rotational Rheometer with P35TiL parallel-plate. The gap was set to $0.50 \mathrm{~mm}$. About $0.50 \mathrm{~mL} \mathrm{OB}$ emulsions with a low and high concentration of ALG, which were prepared as described in Section 2.4, were placed between the plates. The excess sample was removed and silicone oil was covered at the periphery of the exposed portion of the sample to prevent evaporation of water. The measurements were performed at a constant temperature of $25.0^{\circ} \mathrm{C} \pm 0.1^{\circ} \mathrm{C}$. The shear rate was increased from $10 \mathrm{~s}^{-1}$ to $500 \mathrm{~s}^{-1}$, and the viscosity was recorded as a function of the shear rate.

\subsection{Data Analysis}

Each emulsion sample was prepared at least three times, and each measurement of emulsion physicochemical properties was conducted at least in triplicates. Therefore, at least 9 analyses were done for each parameter of a sample, and the statistics were calculated to get the average value with the standard deviation.

\section{Conclusions}

This study showed that the peanut, sesame, and rapeseed OBs extracted by the aqueous extraction method have different types and contents of endogenous and exogenous proteins. At acidic conditions near the IEP of their emulsions, $0.35 \mathrm{wt} . \%, 0.45 \mathrm{wt} . \%$, and $0.30 \mathrm{wt} . \%$ ALG could stabilize the $1 \mathrm{wt} . \%$ peanut, sesame, and rapeseed OB emulsions, respectively. At this condition, ALG molecules adsorb onto the surface of the OBs through electrostatic interaction, balance a certain positive charge, and enhance the repulsion between the OB droplets, stabilizing the emulsions. For different OBs, the optimum ALG concentration was different, which might be related to the surface protein types and contents of the extracted OBs. These low-concentration ALG-coated OB emulsions showed better storage, salt tolerance, and freeze-thaw resistance than the pure $\mathrm{OB}$ emulsions. However, a serious creaming phenomenon was observed in the emulsions at $\mathrm{pH} 7-8$. By increasing the concentration of ALG, we successfully solved this problem, and the creaming stability of the $\mathrm{OB}$ emulsions was much improved through the viscosity effect. The salt tolerance, temperature stability, and freeze-thaw resistance of the OB emulsions were also significantly improved by adding the high concentration ALG to this neutral condition. 
Supplementary Materials: Are available online.

Author Contributions: Conceptualization, N.Y.; methodology and data acquisition, Y.Z., Y.X., Q.W., and P.H.; formal analysis, Y.Z. and N.Y.; funding acquisition, N.Y.; investigation, Y.Z. and N.Y.; writing-original draft preparation, Y.Z.; writing — review and editing, N.Y., K.N., and Y.F.

Funding: This research was funded by the National Natural Science Foundation of China $(31571797,31401649)$ the National Key Research and Development Program of China (No. 2017YFD0400200) and the Hubei Provincial Department of Education (D20181403). Nan Yang was also supported by the Chinese Scholarship Council (CSC 201708420099) and the Hubei University of Technology (YXQN2016001).

Conflicts of Interest: There are no conflicts to declare.

\section{References}

1. Frandsen, G.I.; Mundy, J.; Tzen, J.T.C. Oil bodies and their associated proteins, oleosin and caleosin. Physiol. Plant. 2001, 112, 301-307. [CrossRef] [PubMed]

2. Lin, L.J.; Liao, P.C.; Yang, H.H.; Tzen, J.T. Determination and analyses of the N-termini of oil-body proteins, steroleosin, caleosin and oleosin. Plant Physiol. Biochem. 2005, 43, 770-776. [CrossRef] [PubMed]

3. Alexander, L.G.; Sessions, R.B.; Clarke, A.R.; Tatham, A.S.; Shewry, P.R.; Napier, J.A. Characterization and modelling of the hydrophobic domain of a sunflower oleosin. Planta 2002, 214, 546-551. [CrossRef] [PubMed]

4. Nikiforidis, C.V.; Matsakidou, A.; Kiosseoglou, V. Composition, properties and potential food applications of natural emulsions and cream materials based on oil bodies. RSC Adv. 2014, 4, 25067-25078. [CrossRef]

5. Qu, R.D.; Huang, A.H. Oleosin KD 18 on the surface of oil bodies in maize. Genomic and cDNA sequences and the deduced protein structure. J. Biol. Chem. 1990, 265, 2238-2243.

6. Gohon, Y.; Vindigni, J.D.; Pallier, A.; Wien, F.; Celia, H.; Giuliani, A.; Tribet, C.; Chardot, T.; Briozzo, P. High water solubility and fold in amphipols of proteins with large hydrophobic regions: Oleosins and caleosin from seed lipid bodies. Biochim. Biophys. Acta BBA Biomembr. 2011, 1808, 706-716. [CrossRef]

7. Jiang, P.L.; Tzen, J.T. Caleosin serves as the major structural protein as efficient as oleosin on the surface of seed oil bodies. Plant Signal. Behav. 2010, 5, 447-449. [CrossRef]

8. Huang, A. Oleosins and oil bodies in seeds and other organs. Plant Physiol. 1996, 110, 1055-1061. [CrossRef]

9. Tai, S.S.K.; Chen, M.C.M.; Peng, C.C.; Tzen, J.T.C. Gene family of oleosin isoforms and their structural stabilization in sesame seed oil bodies. Biosci. Biotechnol. Biochem. 2002, 66, 2146-2153. [CrossRef]

10. Lin, L.J.; Tai, S.S.; Peng, C.C.; Tzen, J.T. Steroleosin, a sterol-binding dehydrogenase in seed oil bodies. Plant Physiol. 2002, 128, 1200-1211.

11. Fisk, I.D.; White, D.A.; Carvalho, A.; Gray, D.A. Tocopherol-An intrinsic component of sunflower seed oil bodies. J. Am. Oil Chem. Soc. 2006, 83, 341-344. [CrossRef]

12. White, D.A.; Fisk, I.D.; Makkhun, S.; Gray, D.A. In vitro assessment of the bioaccessibility of tocopherol and fatty acids from sunflower seed oil bodies. J. Agric. Food Chem. 2009, 57, 5720-5726. [CrossRef] [PubMed]

13. White, D.; Fisk, I.; Gray, D.; White, D.; Gray, D. Characterisation of oat (Avena sativa L.) oil bodies and intrinsically associated E-vitamers. J. Cereal Sci. 2006, 43, 244-249. [CrossRef]

14. Wu, N.N.; Huang, X.; Yang, X.Q.; Guo, J.; Yin, S.W.; He, X.T.; Wang, L.J.; Zhu, J.H.; Qi, J.R.; Zheng, E.L. In vitro assessment of the bioaccessibility of fatty acids and tocopherol from soybean oil body emulsions stabilized with ı-carrageenan. J. Agric. Food Chem. 2012, 60, 1567-1575. [CrossRef] [PubMed]

15. Tzen, J.T.; Lie, G.C.; Huang, A.H. Characterization of the charged components and their topology on the surface of plant seed oil bodies. J. Biol. Chem. 1992, 267, 15626-15634.

16. Iwanaga, D.; Gray, D.; Decker, E.A.; Weiss, J.; McClements, D.J. Stabilization of soybean oil bodies using protective pectin coatings formed by electrostatic deposition. J. Agric. Food Chem. 2008, 56, 2240-2245. [CrossRef]

17. Zielbauer, B.I.; Jackson, A.J.; Maurer, S.; Waschatko, G.; Ghebremedhin, M.; Rogers, S.E.; Heenan, R.K.; Porcar, L.; Vilgis, T.A. Soybean oleosomes studied by small angle neutron scattering (SANS). J. Colloid Interface Sci. 2018, 529, 197-204. [CrossRef]

18. Nikiforidis, C.V.; Kiosseoglou, V. Physicochemical stability of maize germ oil body emulsions as influenced by oil body surface-xanthan gum interactions. J. Agric. Food Chem. 2010, 58, 527-532. [CrossRef]

19. Shakerardekani, A.; Karim, R.; Mirdamadiha, F. The effect of sorting on aflatoxin reduction of pistachio nuts. J. Food Agric. Environ. 2012, 10, 459-461. [CrossRef] 
20. Matsakidou, A.; Biliaderis, C.G.; Kiosseoglou, V. Preparation and characterization of composite sodium caseinate edible films incorporating naturally emulsified oil bodies. Food Hydrocoll. 2013, 30, 232-240. [CrossRef]

21. Nikiforidis, C.V.; Biliaderis, C.G.; Kiosseoglou, V. Rheological characteristics and physicochemical stability of dressing-type emulsions made of oil bodies-egg yolk blends. Food Chem. 2012, 134, 64-73. [CrossRef]

22. Iwanaga, D.; Gray, D.A.; Fisk, I.D.; Decker, E.A.; Weiss, J.; McClements, D.J. Extraction and characterization of oil bodies from soy beans: A natural source of pre-emulsified soybean oil. J. Agric. Food Chem. 2007, 55, 8711-8716. [CrossRef] [PubMed]

23. Wu, N.N.; Yang, X.Q.; Teng, Z.; Yin, S.W.; Zhu, J.H.; Qi, J.R. Stabilization of soybean oil body emulsions using $\kappa, l, \lambda$-carrageenan at different $\mathrm{pH}$ values. Food Res. Int. 2011, 44, 1059-1068. [CrossRef]

24. Sukhotu, R.; Guo, S.; Xing, J.; Hu, Q.; Wang, R.; Shi, X.; Nishinari, K.; Fang, Y.; Guo, S. Changes in physiochemical properties and stability of peanut oil body emulsions by applying gum arabic. LWT Food Sci. Technol. 2016, 68, 432-438. [CrossRef]

25. Nikiforidis, C.V.; Donsouzi, S.; Kiosseoglou, V. The interplay between diverse oil body extracts and exogenous biopolymers or surfactants. Food Res. Int. 2016, 83, 14-24. [CrossRef]

26. Chen, B.; McClements, D.J.; Gray, D.A.; Decker, E.A. Stabilization of soybean oil bodies by enzyme (Laccase) cross-linking of adsorbed beet pectin coatings. J. Agric. Food Chem. 2010, 58, 9259-9265. [CrossRef]

27. Chen, B.; McClements, D.J.; Decker, E.A. Role of continuous phase anionic polysaccharides on the oxidative stability of menhaden oil-in-water emulsions. J. Agric. Food Chem. 2010, 58, 3779-3784. [CrossRef]

28. Hu, G.H. Functional Food Gum; Chemical Industry Press: Beijing, China, 2008.

29. Su, C.; Feng, Y.; Ye, J.; Zhang, Y.; Gao, Z.; Zhao, M.; Yang, N.; Nishinari, K.; Fang, Y. Effect of sodium alginate on the stability of natural soybean oil body emulsions. RSC Adv. 2018, 8, 4731-4741. [CrossRef]

30. Payne, G.; Lad, M.; Foster, T.; Khosla, A.; Gray, D.; Foster, T. Composition and properties of the surface of oil bodies recovered from Echium plantagineum. Colloids Surf. B Biointerfaces 2014, 116, 88-92. [CrossRef]

31. Cao, Y.Y.; Zhao, L.P.; Ying, Y.S.; Kong, X.Z.; Hua, Y.F.; Chen, Y.M. The characterization of soybean oil body integral oleosin isoforms and the effects of alkaline $\mathrm{pH}$ on them. Food Chem. 2015, 177, 288-294. [CrossRef]

32. Deleu, M.; Vaca-Medina, G.; Fabre, J.F.; Rö̈z, J.; Valentin, R.; Mouloungui, Z. Interfacial properties of oleosins and phospholipids from rapeseed for the stability of oil bodies in aqueous medium. Colloids Surf. B Biointerfaces 2010, 80, 125-132. [CrossRef] [PubMed]

33. Ishii, T.; Matsumiya, K.; Nambu, Y.; Samoto, M.; Yanagisawa, M.; Matsumura, Y.; Matsuymiya, K. Interfacial and emulsifying properties of crude and purified soybean oil bodies. Food Struct. 2017, 12, 64-72. [CrossRef]

34. Zhao, L.P.; Chen, Y.M.; Chen, Y.J.; Kong, X.Z.; Hua, Y.F. Effects of pH on protein components of extracted oil bodies from diverse plant seeds and endogenous protease-induced oleosin hydrolysis. Food Chem. 2016, 200, 125-133. [CrossRef] [PubMed]

35. Zhao, G.; Liu, Y.; Zhao, M.; Ren, J.; Yang, B. Enzymatic hydrolysis and their effects on conformational and functional properties of peanut protein isolate. Food Chem. 2011, 127, 1438-1443. [CrossRef]

36. Ying, Y.S.; Zhao, L.P.; Kong, L.Z.; Kong, X.Z.; Hua, Y.F.; Chen, Y.M. Solubilization of proteins in extracted oil bodies by SDS: A simple and efficient protein sample preparation method for Tricine-SDS-PAGE. Food Chem. 2015, 181, 179-185. [CrossRef] [PubMed]

37. Tzen, J.T.C.; Lai, Y.K.; Chan, K.L.; Huang, A.H.C. Oleosin Isoforms of high and low molecular weights are present in the oil bodies of diverse seed species. Plant Physiol. 1990, 94, 1282-1289. [CrossRef]

38. De Chirico, S.; Di Bari, V.; Foster, T.; Gray, D. Enhancing the recovery of oilseed rape seed oil bodies (oleosomes) using bicarbonate-based soaking and grinding media. Food Chem. 2018, 241, 419-426. [CrossRef]

39. Güzey, D.; McClements, D.J. Impact of electrostatic interactions on formation and stability of emulsions containing oil droplets coated by $\beta$-lactoglobulin-pectin complexes. J. Agric. Food Chem. 2007, 55, 475-485. [CrossRef]

40. Maurer, S.; Waschatko, G.; Schach, D.; Zielbauer, B.I.; Dahl, J.; Weidner, T.; Bonn, M.; Vilgis, T.A. The role of intact oleosin for stabilization and function of oleosomes. J. Phys. Chem. B 2013, 117, 13872-13883. [CrossRef]

41. Keddie, J.S.; Edwards, E.W.; Gibbons, T.; Shaw, C.H.; Murphy, D.J. Sequence of an oleocin cDNA from Brassica napus. Plant Mol. Biol. 1992, 19, 1079-1083. [CrossRef]

42. Barre, A.; Simplicien, M.; Cassan, G.; Benoist, H.; Rougé, P. Oil bodies (oleosomes): Occurrence, structure, allergenicity. Rev. Fr. D'allergologie 2018, 58, 574-580. [CrossRef] 
43. Waschatko, G.; Schiedt, B.; Vilgis, T.A.; Junghans, A.; Junghans, S.A. Soybean oleosomes behavior at the air-water interface. J. Phys. Chem. B 2012, 116, 10832-10841. [CrossRef] [PubMed]

44. Wu, N.N.; Huang, X.; Yang, X.Q.; Guo, J.; Zheng, E.L.; Yin, S.W.; Zhu, J.H.; Qi, J.R.; He, X.T.; Zhang, J.B. Stabilization of soybean oil body emulsions using l-carrageenan: Effects of salt, thermal treatment and freeze-thaw cycling. Food Hydrocoll. 2012, 28, 110-120. [CrossRef]

45. Zhao, Z.G. Apply Colloid and Interface Chemistry; Chemical Industry Press: Beijing, China, 2008; p. 55.

46. Güzey, D.; McClements, D.J. Formation, stability and properties of multilayer emulsions for application in the food industry. Adv. Colloid Interface Sci. 2006, 128, 227-248. [CrossRef] [PubMed]

47. Gu, Y.S.; Decker, E.A.; McClements, D.J. Application of multi-component biopolymer layers to improve the freeze-thaw stability of oil-in-water emulsions: $\beta$-Lactoglobulin-l-carrageenan-gelatin. J. Food Eng. 2007, 80, 1246-1254. [CrossRef]

48. Walstra, P. Principles of emulsion formation. Chem. Eng. Sci. 1993, 48, 333-349. [CrossRef]

49. AOAC. Official Methods of Analysis of International; Association of Official Analytical Chemists: Arlington, VA, USA, 2000.

Sample Availability: Samples of the compounds are available from the authors.

(C) 2019 by the authors. Licensee MDPI, Basel, Switzerland. This article is an open access article distributed under the terms and conditions of the Creative Commons Attribution (CC BY) license (http://creativecommons.org/licenses/by/4.0/). 